\title{
DISTANCE TO FITNESS ZONE, USE OF FACILITIES AND PHYSICAL ACTIVITY IN ADULTS
}

\author{
DISTÂNCIA ATÉAS ACADEMIAS AO ARLIVRE, USO DAS ESTRUTURASEATIVIDADE FISICA EM ADULTOS
}

DISTANCIA A LOS GIMNASIOS AL AIRELIBRE, USO DE LAS ESTRUCTURAS Y ACTIVIDAD FISICA DEADULTOS

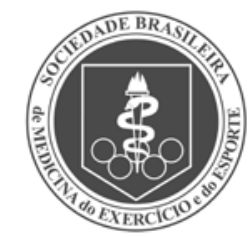

Original Article

Artigo Original

Artículo Original
Alice Tatiane da Silva 1,2,3

(Physical Education Professional)

Rogério César Fermino 2,4

(Physical Education Professional)

Adalberto Aparecido dos Santos Lopes $^{1,2}$

(Physical Education Professional)

Claudia Oliveira Alberico ${ }^{2,5}$

(Physical Education Professional)

Rodrigo Siqueira Reis 1,2,6

(Physical Education Professional)

1. Universidade Federal do Paraná, Programa de Pós-Graduação em

Educação Física. Curitiba, PR, Brazil. 2. Pontifícia Universidade Católica do Paraná, Grupo de Pesquisa em Atividade Física e Qualidade de Vida (GPAQ). Curitiba, PR, Brazil.

3. Secretaria Municipal de Esporte e Lazer (SEMEL). Departamento de Lazer. São José dos Pinhais,

PR, Brazil.

4. Universidade Tecnológica Federal do Paraná, Programa de Pós-Graduação em Educação Física (PPGEF). Grupo de Pesquisa em Ambiente, Atividade Física e Saúde (GPAAFS). Curitiba, PR, Brazil. 5. North Carolina State University. Center for Geospatial Analytics. Department of Parks, Recreation and Tourism Management. Raleigh, NC, United States of America. 6. Washington University in St Louis. Brown School. Prevention Research Center. St Louis, MO, United States of America.

\section{Correspondence:}

Pontifícia Universidade Católica do Paraná. Grupo de Pesquisa em Atividade Física e Qualidade de Vida (GPAQ). Rua Imaculada Conceição, 1.155, Prado Velho, Curitiba,

PR, Brazil. 80215-901.

silva.alice@outlook.com

\begin{abstract}
Introduction: The characteristics of the built environment are important predictors of physically active behavior. In this regard, the presence, availability, access to and quality of public open spaces for physical activity close to home are positively associated with their use and higher levels of physical activity in the population. Objective: To analyze the association between distance from home to outdoor fitness zones with the use of these facilities and physical activity in adults from Curitiba, Brazil. Methods: Cross-sectional study conducted with 328 users of 20 outdoor fitness zones. Distance was calculated with the Geographic Information System (GIS) using the street network in ArcGIS 10.1 and classified in tertiles ( $\leq 854$ meters; 855-1741 meters; $\geq 1742$ meters). To assess the use of the facilities, three attributes were considered: weekly frequency (times/week), length of stay (minutes/day) and length of use (months). The leisure module of the International Physical Activity Questionnaire (IPAQ) assessed physical activity, and travel to the destination was classified as "passive" or "active". The association was tested using Poisson regression in STATA 12.0. Results: An inverse association was found between the upper tertile of distance from home to the outdoor fitness zones and active commuting (PR: $0.70 ; 95 \%$ Cl: $0.51-0.97$ ), and $\geq 31 \mathrm{~min} /$ day length of stay (PR: $0.49 ; 95 \% \mathrm{Cl}: 0.31-0.76$ ). Conclusion: Reducing distances and increasing the number of facilities may increase physical activity through active commuting and length of stay at outdoor fitness zones.
\end{abstract}

Keywords: Motor activity; Green areas; Parks, Recreational; Environment and Public Health; Epidemiologic studies.

\section{RESUMO}

Introdução: As características do ambiente construído são importantes preditores do comportamento fisicamente ativo. Nesse sentido, a presença, a disponibilidade, o acesso e a qualidade dos espaços públicos abertos para a a tividade física próximos à residência são positivamente associados a seu uso e a maiores níveis de atividade física da população. Objetivo: Analisar a associação entre a distância da residência a té as academias ao ar livre com o uso destas estruturas e a prática de atividades físicas em adultos de Curitiba, Brasil. Métodos: Estudo transversal realizado com 328 frequentadores de 20 academias ao ar livre. A distância foi calculada como Sistema de Informação Geográfica (SIG), utilizando a rede de ruas no software ArcGIS 10.1 e classificada em tercis ( $\leq 854$ metros; $855-1.741$ metros; $\geq 1.742$ metros). O uso das academias ao ar livrefoi avaliado com baseem três indicadores: frequência semanal (vezes/semana), tempo depermanência (minutos/dia) e tempo de uso (meses). A atividade física foi avaliada com o módulo de lazer do International Physical Activity Questionnaire (IPAQ) eo deslocamento até os locais foi classificado como "passivo" ou "ativo". A associação foi testada com a regressão de Poisson no STATA 12.0. Resultados: Foiverificada associação inversa entre o tercil superior de distância da residência até as academias ao ar livre com o des/ocamento ativo (RP:0,70;/C95\%:0,51-0,97) eo tempo de permanência $\geq 31 \mathrm{~min} /$ dia nesses locais (RP: 0,49; IC95\%: 0,37-0,76). Conclusões: Diminuir as distâncias e aumentar o número dessas estruturas facilitaria o deslocamento ativo e o tempo de permanência nesses locais para a prática de atividades físicas.

Descritores: Atividade motora; Áreas verdes; Parques recreativos; Meio ambiente e saúde pública; Estudos epidemiológicos.

\section{RESUMEN}

Introducción: Las características del ambiente construido son importantes predictores del comportamiento físicamente activo. En este sentido, la presencia, la disponibilidad, el acceso y la calidad de los espacios públicos abiertos para la actividad física cercanos a la residencia están positivamente asociados a su uso y a mayores niveles de actividad física de la población. Objetivo: Analizar la asociación entre la distancia de la residencia hasta los gimnasios al aire libre para usar esas estructuras y practicar actividades físicas de adultos de Curitiba, Brasil. Métodos: Estudio transversal realizado con 328 frecuentadores de 20 gimnasios al aire libre. La distancia fue calculada con el Sistema de Información Geográfica (SIG) utilizando la red de calles en el software ArcGIS 10.1 y clasificada en terciles ( $\leq 854$ metros, 855-1.741 metros; $\geq 1.742$ metros). El uso de los gimnasios al aire libre fue evaluado con base en tres indicadores: frecuencia semanal (veces/semana), tiempo de permanencia (minutos/día) y tiempo de uso (meses). La actividad física se evaluó con el módulo de ocio del International Physical Activity Questionnaire (IPAQ) y el desplazamiento hasta los locales fue clasificado como "pasivo" o "activo". La asociación fue probada con la regresión de Poisson en STATA 12.0. Resultados: Se observó asociación inversa entre el tercil superior de distancia de la residencia hasta el gimnasio 
al aire libre con el desplazamiento activo (RP: 0,70; IC95\%:0,51-0,97) y el tiempo de permanencia $\geq 31 \mathrm{~min} /$ día en esos lugares (RP: 0,49; IC95\%: 0,37-0,76). Conclusiones: Disminuir las distancias y aumentar el número de esas estructuras facilitaría el desplazamiento activo y el tiempo de permanencia en esos lugares para la práctica de actividades físicas.

Descriptores: Actividad motora; Áreas verdes; Parques recreativos; Medio ambiente y salud pública; Estudios epidemiológicos.

\section{INTRODUCTION}

Evidence shows that several characteristics of the built environment in urban cities are important predictors of physical activity, especially in commuting and leisure. ${ }^{1-4}$ Presence, availability, access and quality of public open spaces for physical activity near home are positively associated to the use of those spaces for leisure and physical activity., ${ }^{5,6}$

Results from a national telephone-based survey in Brazil (VIGITEL) revealed a $67 \%$ increase in the probability of practicing physical activity in leisure time for adults, when adequate physical activity locations were available near their home ${ }^{7}$. However, other studies show this association varies according to characteristics of the locations and type of physical activity. ${ }^{8}$ For example, the proximity from home to sport and leisure centers (places with different areas and structures for physical activity) increases in 126\% the probability of walking, while the number of fitness centers improves in 52\% the probability of moderate to vigorous physical activity in leisure time. ${ }^{8}$

Since the 1960's, Curitiba has invested in public policy related to health promotion associated to public space remodeling to become more appropriate for physical activity. ${ }^{9,10}$ These spaces include parks, plazas, green areas, and recreation centers, with several areas, structures and equipment for physical activity.,10 These places are often used by the community and frequency to parks and plazas has been found positively associated to higher levels of leisure time physical activity., 11,12

Starting in 2008, outdoor gyms known as fitness zones were installed throughout the city, as stationary facilities for aerobics exercises, muscular strengthening, stretching and articular mobility. ${ }^{13}$ In Curitiba, there were 196 fitness zones units available ${ }^{14}$ by December 2017. Limited evidence is available on fitness zones, but it is known women, middle-aged and physically active people use them more frequently. 13,15,16 Nonetheless, no other studies have explored the association between distance from home to fitness zones and the use of facilities and level of physical activity.

The understanding of this relationship is important so that municipal managers have a solid support to optimize resources for implementation and maintenance of these structures, prioritizing the access and, consequently, use of fitness zones. Furthermore, as a result, it is possible to attenuate the inequality in access to physical activity, with positive results for community health. Therefore, the aim of this study was to analyze the association between distance from home to fitness zones, use of structures and physical activity in adults from Curitiba, Brazil.

\section{MATERIALS AND METHODS}

\section{Study design, characteristics and ethics}

The present study is part of a project entitled "Fitness zone of Curitiba: effects on the physical activity level and quality of life of the population". ${ }^{13} \mathrm{In}$ 2012, a cross-sectional study was conducted with face-to-face intercept interviews, in which participated adult users of 20 fitness zones in the city of Curitiba. Protocols followed ethical recommendations, participants signed a consent form and the Ethics Committee in Research at PUCPR approved all procedures (85.033/2012).

\section{Site selection and data collection}

A total of 100 fitness zone were installed in Curitiba in the beginning of the project. Twenty were systematically selected to guarantee representation, according to population density and income. Further details on the selection and characteristics of the fitness zones can be consulted in the literature. ${ }^{13}$

Fifteen interviewers were trained, and instructed to approach the highest number of adults ( $\geq 18$ years) who were using fitness zones equipment for physical activity during data collection. In case no one was found there, researchers had to remain in the area for one hour to wait for possible users. Surveys were conducted in two week days (Monday and Thursday) and two weekend days (Saturday and Sunday), in four periods of the day (8:00-9:00, 11:00-12:00, 14:00-15:00, 17:00-18:00).

The survey was created based on other instruments developed for similar studies in the United States ${ }^{17}$ which was translated, adapted to the Brazilian context and applied in other studies in Curitiba. ${ }^{12,13}$

\section{Dependent variable}

The use of fitness zones was assessed based on three indicators: weekly frequency (times per week), length of stay (minutes per day) and length of use (months). Weekly frequency was assessed by the question: "How often do you come to this fitness zones?", which was categorized in " $\leq 2$ times/ week" and " $\geq 3$ times/week". Length of stay was assessed by the question: "On a habitual day you come to a fitness zones, how long do you stay in this location?", operationalized in " $\leq 30 \mathrm{~min} /$ day" and " $\geq 31 \mathrm{~min} /$ day". The length of use was assessed by the question: "How long have you been using this fitness zones?" operationalized in " $\leq 11$ months" and " $\geq 12$ months". Details on variables, responses and scales may be consulted in previous publications. ${ }^{13}$

\section{Leisure time physical activity}

Weekly habitual physical activity was assessed by the leisure module of The International Physical Activity Questionnaire (IPAQ). Walking and total physical activity were analyzed separately, and both were catego-

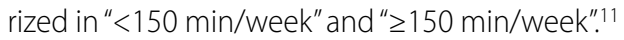

\section{Commute to fitness zones}

The type of commute to fitness zones was assessed by the question "Usually, how do you commute to this fitness zone?". Response options were categorized in "passive commute" (car, motorcycle, public transport), and "active commute" (walking or riding a bicycle). ${ }^{11}$

\section{Independent variable}

To assess distance from participants'home to the fitness zones where they were surveyed, a database was organized with home location information (street name, number and postal code). Data on incomplete addresses were excluded (20\%).

Participants' homes and fitness zones were geocoded on ArcGIS 10.1 from $E S R I^{\circledR}$. The smallest distance from home to the locations was calculated with Geographic Information System (GIS) using street network. For analysis, this variable was categorized in tertiles and classified in three levels ( $1^{\text {st }}$ tertile: $\leq 854$ meters; $2^{\text {nd }}$ tertile: $855-1,741$ meters; $3^{\text {rd }}$ tertile: $\geq 1,742$ meters). (Figure 1) 


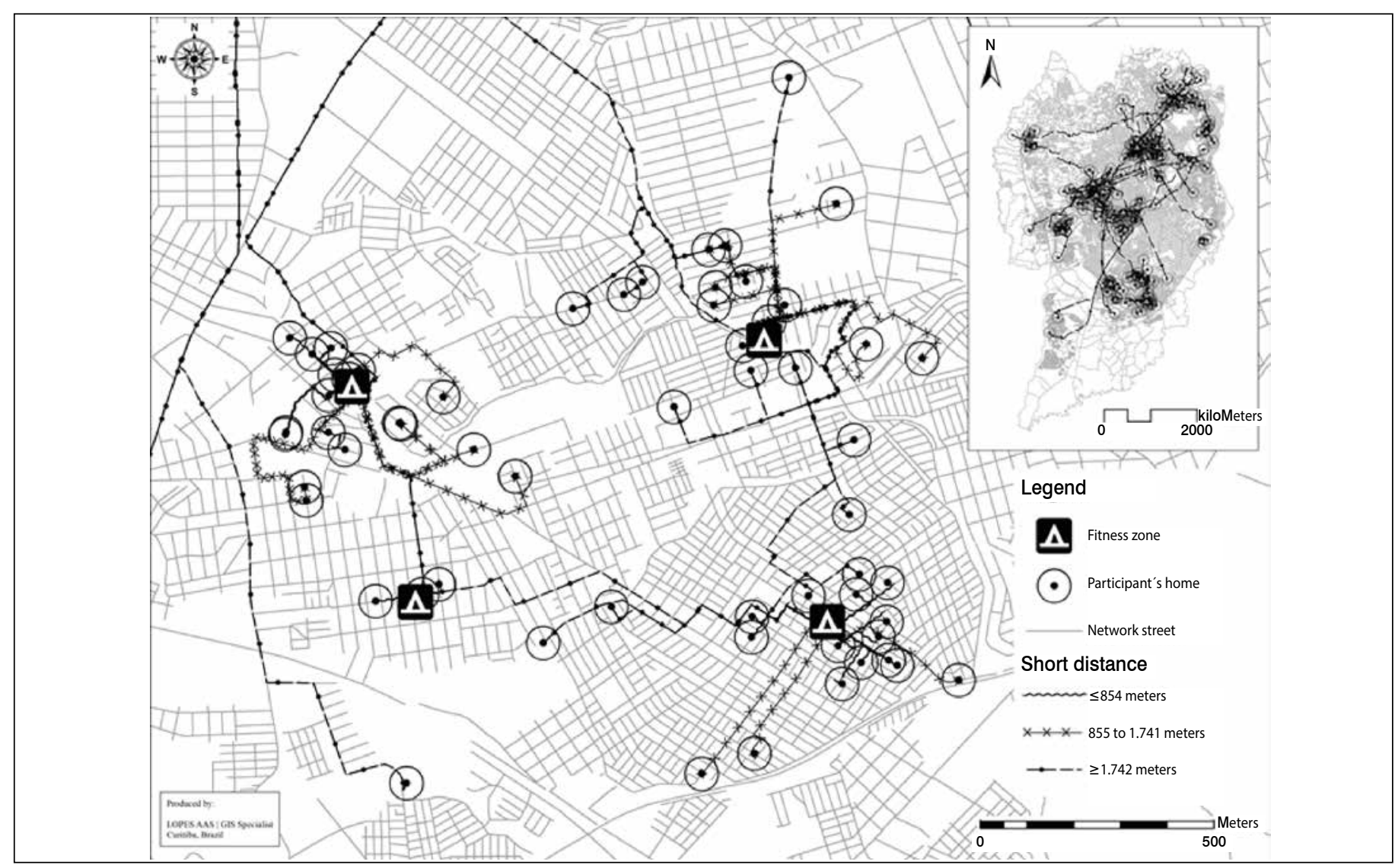

Figure 1. Smallest distance over street network, from home to fitness zone where participants were surveyed. Curitiba-PR, Brazil, 2012 (n=328).

\section{Covariables}

Variables potentially associated to physical activity and/or use of public open spaces were identified in the literature review: individual, sociodemographic, psychosocial and safety perception. 10,13,18-20 These variables were tested as possible covariables and the description follows.

\section{Individual and sociodemographic variables}

Gender ("male","female") was observed, age was categorized in"18-59 years" and " $\geq 60$ years", and marital status classified as "single" (single, separated, widowed) or "married" (married, living with a partner). Education was classified in "high school" and "higher education", while household income " $\leq R \$ 2,999.00$ " and " $\geq R \$ 3,000.00$ ". Body mass index (BMI) was calculated based on self-reported weight and height and participants classified in "normal weight" $\left(24.9 \mathrm{~kg} / \mathrm{m}^{2}\right)$ and "overweight" $\left(\geq 25.0 \mathrm{~kg} / \mathrm{m}^{2}\right)$.

\section{Psychosocial variables}

Social support was assessed through three questions on weekly frequency of an invitation from a family member or friend, company or encouragement to go to a fitness zone fitness zone.21 Questions had three possible responses: "never" (cod:: 0), "sometimes" (cod.: 1) and "always" (cod.: 2). For analysis, the social support score was summarized and classified in: "0 points","1-3 points" and " $\geq 4$ points".

\section{Safety perception to use fitness zones}

This variable was assessed based in three independent questions about safety perception to use fitness zone in the morning, afternoon and evening ${ }^{22}$. The responses were in a five-point Likert scale (totally disagree, partially disagree, don't disagree/agree, partially agree and totally agree). The variable was operationalized in "poor" perception (totally/partially disagree), "not poor/not good" (don't disagree/agree) and "good" (totally/partially agree).

\section{Statistical analysis}

Descriptive analysis of distance to fitness zone included mean, median and range. Absolute and relative frequencies were used to compare proportions of dependent variables and the tertiles of distance to fitness zone. Poisson regression was used to test association between the variables. Multivariate associations were analyzed according to the following models:"model 1"- adjusted for sociodemographic variables (gender, age, marital status, education, household income and BMI); "model 2" - adjusted for psychosocial variables (social support from family and friends);"model 3"- adjusted for safety perception (morning, afternoon and evening). Variables analyzed with forced entry method on STATA 12.0 and the level of significance set at 5\%.

\section{RESULTS}

Final analytical sample was 328 participants (54.3\% women). (Table 1) A larger proportion of participants were between $18-59$ years (65.0\%), married (65.5\%), higher education (54.9\%), monthly household income $\geq R \$ 3,000.00$ (54.3\%) and overweight (59.3\%). About 40\% of the sample scored between 1-3 points in the family social support score. Almost half of participants (48.0\%) did not have social support from friends to use fitness zone ( 0 point score). Most participants reported good safety perception to use fitness zone in the morning (86.3\%) and afternoon (78.9\%) while 59\% reported poor perception of safety to use the locations during the evening. (Table 1)

Approximately seven in every 10 participants, use the fitness zone $\geq 3$ times/week, and remained in the locations for $\geq 31$ minutes/day. About $50 \%$ used fitness zone for a period of 12 months or more (Table 1), and $56.7 \%$ practiced walking for $<150 \mathrm{~min} /$ week. Also, seven out of 10 reported $\geq 150 \mathrm{~min} /$ week of total leisure time physical activity (71.9\%), while $85.9 \%$ were active when going from home to fitness zone. 
Table 1. Characteristics of users of fitness zone. Curitiba, PR, Brazil, $2012(n=328)$.

\begin{tabular}{|c|c|c|c|}
\hline Variables & Categories & $\mathrm{n}$ & $\%$ \\
\hline \multicolumn{4}{|l|}{ Sociodemographic } \\
\hline \multirow{2}{*}{ Gender } & Male & 150 & 45.7 \\
\hline & Female & 178 & 54.3 \\
\hline \multirow{2}{*}{ Age } & $18-59$ years & 211 & 65.0 \\
\hline & $\geq 60$ years & 117 & 35.0 \\
\hline \multirow{2}{*}{ Marital status } & Single & 113 & 34.5 \\
\hline & Married & 215 & 65.5 \\
\hline \multirow{2}{*}{ Education } & Up to high school & 105 & 45.1 \\
\hline & Higher education & 128 & 54.9 \\
\hline \multirow{2}{*}{ Household income (R\$) } & $\leq 2,999.99$ & 177 & 46.6 \\
\hline & $\geq 3,000.00$ & 110 & 54.3 \\
\hline \multirow{2}{*}{ Body mass index (BMI) } & Normal & 132 & 40.7 \\
\hline & Overweight & 192 & 59.3 \\
\hline \multicolumn{4}{|l|}{ Psychosocial } \\
\hline \multirow{3}{*}{ Social support from family (points) } & 0 & 116 & 38.7 \\
\hline & $1-3$ & 119 & 39.7 \\
\hline & $4-6$ & 65 & 21.6 \\
\hline \multirow{3}{*}{$\begin{array}{l}\text { Social support from friends } \\
\text { (points) }\end{array}$} & 0 & 144 & 48.0 \\
\hline & $1-3$ & 112 & 37.3 \\
\hline & $4-6$ & 44 & 14.7 \\
\hline \multicolumn{4}{|l|}{$\begin{array}{c}\text { Safety perception to use } \\
\text { fitness zone }\end{array}$} \\
\hline \multirow{3}{*}{ Morning } & Poor & 12 & 3.7 \\
\hline & Not poor nor good & 33 & 10.0 \\
\hline & Good & 283 & 86.3 \\
\hline \multirow{3}{*}{ Afternoon } & Poor & 20 & 6.1 \\
\hline & Not poor nor good & 49 & 15.0 \\
\hline & Good & 258 & 78.9 \\
\hline \multirow{3}{*}{ Evening } & Poor & 191 & 58.8 \\
\hline & Not poor nor good & 67 & 20.6 \\
\hline & Good & 67 & 20.6 \\
\hline \multicolumn{4}{|l|}{ Use of fitness zone } \\
\hline \multirow{2}{*}{ Weekly frequency of use } & $\leq 2$ times/week & 94 & 30.8 \\
\hline & $\geq 3$ times/week & 211 & 69.2 \\
\hline \multirow{2}{*}{ Length of stay } & $\leq 30 \mathrm{~min} /$ week & 154 & 50.8 \\
\hline & $\geq 31 \mathrm{~min} /$ week & 149 & 49.2 \\
\hline \multirow{2}{*}{ Length of use } & $\leq 11$ months & 169 & 51.5 \\
\hline & $\geq 12$ months & 159 & 48.5 \\
\hline \multicolumn{4}{|l|}{ Physical activity } \\
\hline \multirow{2}{*}{ Leisure walking } & $<150 \mathrm{~min} /$ week & 186 & 56.7 \\
\hline & $\geq 150 \mathrm{~min} /$ week & 142 & 43.3 \\
\hline \multirow{2}{*}{ Total leisure physical activity } & $<150 \mathrm{~min} /$ week & 92 & 28.1 \\
\hline & $\geq 150 \mathrm{~min} /$ week & 235 & 71.9 \\
\hline \multirow{2}{*}{ Commute to fitness zone } & Passive & 43 & 14.1 \\
\hline & Active & 261 & 85.9 \\
\hline
\end{tabular}

(Table 1) Mean distance from home to fitness zone was 2,007 meters (median: 1,276; range: 23.0-25,379 meters).

Participants who lived $\geq 1,742$ meters from fitness zone showed 29\% fewer probability to actively commute to the locations (PR: 0.71; $\left.\mathrm{Cl}_{95 \%}: 0.53-0.97 ; \mathrm{p}=0.034\right)$. This association maintained after adjusting for social support (model $2=P R: 0.70 ; \mathrm{Cl}_{95 \%}: 0.51-0.97 ; \mathrm{p}=0.030$ ). (Figure 2 )

The same group showed a $51 \%$ fewer probability to remain in the locations for $\geq 31 \mathrm{~min} /$ day (PR: 0.49; $\mathrm{Cl}_{95 \%}$ : 0.31-0.76; $\mathrm{p}=0.001$ ). Similar results were found when the analysis was adjusted for social support (model 2 = PR: $0.49 ; \mathrm{Cl}_{95 \%}: 0.31-0.76 ; \mathrm{p}=0.002$ ) and perception of safety (model 3 = PR: 0.54; $\mathrm{Cl}_{95 \%}: 0.35-0.85 ; \mathrm{p}=0.008$ ). (Figure 3)

No significant association was found between distance from home to fitness zone with leisure walking, total physical activity, weekly frequency and length of use of locations (months) ( $p>0.05$ ).

\section{DISCUSSION}

This is the first study that sought to explore the association between distance from home to fitness zone with the use of the structures and physical activity in adults. The methods allowed for the representation of users of fitness zone, as well as the distribution of these structures in the city, besides measuring distance with Geographic Information System (GIS), being one of the strength points of the study. The few national

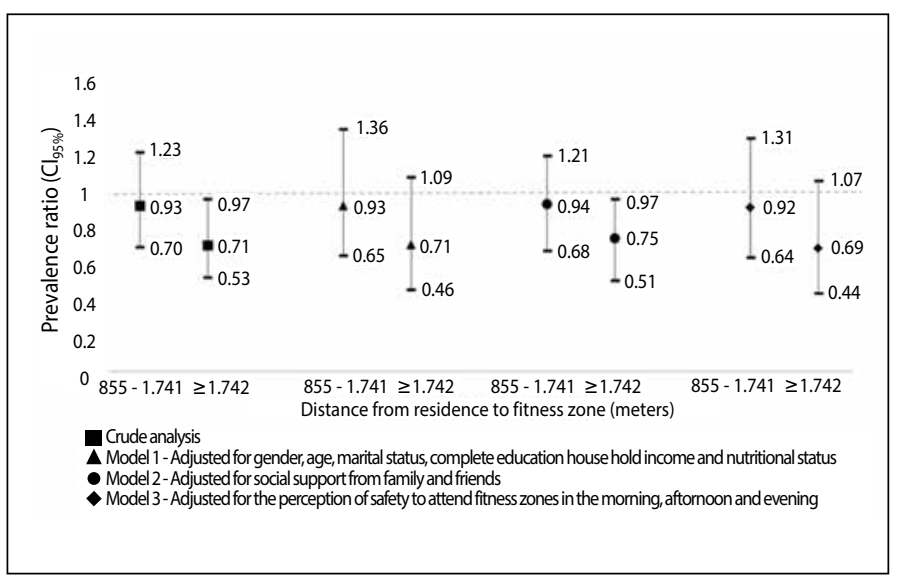

Figure 2. Association between distance from residence to fitness zone with active commuting to the place. Curitiba-PR, Brazil 2012 ( $n=328$ ).

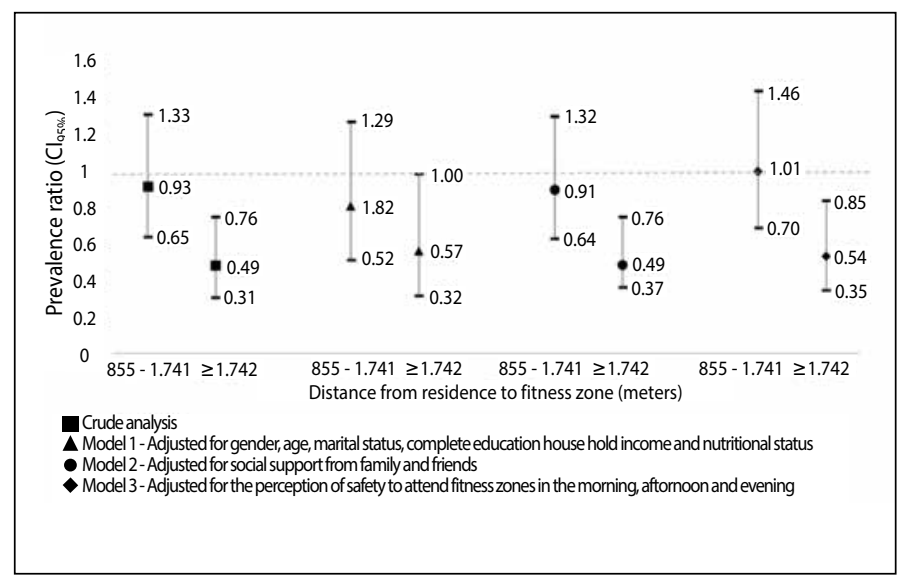

Figure 3. Association between distance from residence to fitness zone with the time spent on the place. Curitiba-PR, Brazil 2012 ( $n=328)$.

studies on the use of fitness zone, authors were limited to describing characteristics and lifestyle of users, reasons to go to locations, and other characteristics of use of these structures. 13,16,23,24

The findings from the present study show an inverse association between the upper tertile of distance from home to fitness zone $(\geq 1,742$ meters) and active commute and length of stay in these locations ( $\geq 31 \mathrm{~min} /$ day). The lack of similar studies limits, in part, comparison and discussion of the results. However, some evidence has looked to identify association between distance/access to parks and its use with physical activity in those places. ${ }^{11,25,26}$ Other studies searched for the association between distance/access to parks, plazas and public open spaces with physical activity levels of individuals in the community., $818-20$

The distance from home to fitness zone of 1,742 meters or more lowered in $29 \%$ the probability of participants being active while commuting to these locations. This result may be partially explained by the need of using motorized vehicles to overcome large distances to fitness zone for physical activity. ${ }^{17}$ Even though no studies were found associating distance to parks and active commute to the spaces, one study in Curitiba evaluated users of parks and plazas and showed $91 \%$ of participants' living $1 \mathrm{~km}$ or more distant from a park, reported easy access to parks and about six out of 10 were active when commuting to the locations..$^{11}$ In the present study, even after adjusting for social support, distance maintained an inverse association with active commute to locations. Even though social support is an important factor associated to physical activity, ${ }_{1}^{2,419}$ this variable was not enough to encourage active commute to fitness zone.

Distance from home to fitness zone of $\geq 1,742$ meters lowered in $51 \%$ the probability of participants to remain in the locations for 31 minutes/ 
day or more. This association may be explained by the time spent commuting from home to the fitness zone, resulting in less available time to remain in the locations for physical activity. ${ }^{27}$ However, a study with users of parks in Los Angeles (USA) showed that, independently from home to park distance, most users remained for at least one hour a day in the locations. ${ }^{17}$ Nonetheless, it is necessary to take into consideration that, the use of fitness zone for physical activity may represent additional rather than primary physical activity. ${ }^{16}$ In Pelotas (Brazil) for example, $66 \%$ of users of fitness zone used those structures because they were walking nearby and used the equipment to supplement this activity. ${ }^{16}$ Another study in Brazil showed that proximity to "Academia da Cidade" program poles was associated to leisure time physical activity in adults. ${ }^{28}$ These results reinforce the assumption that longer distances between home and locations can be an important aspect that inhibits leisure times physical activity, as well as time available for this practice. ${ }^{4,8}$

A few limitations should be considered when interpreting the results of this study. The intentional selection of participants, surveyed in loco, increased the likelihood of including only users who were using fitness zone for physical activity. This characteristic reduces the variability both in exposure as well as the outcomes, reducing the power of associations. Even when considering this possibility, consistent associations were found but the cross-sectional design does not allow a causal relationship to be established. Also, distance was calculated based on the locations of fitness zone where the participants were surveyed, therefore, not necessarily the closest to their homes. During data collection, some participants reported the fitness zone they were in as being closest to their work and that other facilities were available closer to home, being occasionally used by them, so the possibility of self-selection cannot be discarded. Even so, the analyses account for the main confusion factors for physical activity. At last, Curitiba presents a high number of fitness zone throughout the city which, associated to the elevated population density, increases the possibility of these structures being located closer to participants'homes.

\section{CONCLUSION}

Greater distance from home to fitness zone was inversely associated to active commute and length of stay in these units.

Shortening distances and increasing the number of units could facilitate active commute and length of stay in these locations for physical activity. Therefore, installing fitness zone within shorter distances is an information to be considered by managers when planning interventions based on modifications of the built environment in the community, which include construction, maintenance and instruction about the use of fitness zone for promotion of physical activity in the population. Future studies should include a representative sample of those living in the surroundings of fitness zone to identify the prevalence of use, test association between quality of these structures, and public spaces where they are located to the pattern of use, as well as verify the effect of installing fitness zone on the levels of physical activity of the community.

\section{ACKNOWLEDGEMENTS}

The authors would like to thank the Research Group on Physical Activity and Quality of Life (GPAQ/PUCPR) for collaborating in data collection, as well as the Municipal Secretary of Sport, Leisure and Youth (SMELJ) for releasing the information on fitness zone.

\section{FUNDING SOURCE}

ATS (0000-0002-9286-4345) received a grant from the Coordination of Improvement of Higher Education Personnel (CAPES) during the master's. The study was partially funded by the Pontifical Catholic University of Parana (PUCPR).

$\overline{\text { All authors declare no potential conflict of interest related to this article. }}$

AUTHORS' CONTRIBUTIONS: Each author made significant individual contributions to this manuscript. ATS (0000-0002-9286-4345)* participated in the study conception, data analysis, literature review and writing of the manuscript in all its stages; AASL (0000-0002-3001-6412)* participated in data collection, geoprocessing data analysis and writing of the manuscript; COA (0000-0001-8337-7978)*: participated in data collection and review of the manuscript. RCF (0000-0002-9028-4179)*: participated in and coordinated data collection, initial conception of the study, literature review, data analysis, and writing and critical review of the manuscript in all its stages; RSR (0000-00029872-9865)*: was responsible for project conception and coordination as well as critical review of the manuscript. All authors approved the final version of the manuscript. *ORCID (Open Researcher and Contributor ID).

\section{REFERENCES}

1. Humpel N, Owen N, Leslie E. Environmental factors associated with adults' participation in physical activity: a review. Am J Prev Med. 2002;22(3):188-99.

2. Bauman AE, Reis RS, Sallis JF, Wells JC, Loos RJ, Martin BW. Correlates of physical activity: why are some people physically active and others not? Lancet. 2012;380(9838):258-71.

3. Sallis JF, Cerin E, Conway TL, Adams MA, Frank LD, Pratt M, et al. Physical activity in relation to urban environments in 14 cities worldwide: a cross-sectional study. Lancet. 2016;387(10034):2207-17.

4. Duncan MJ, Spence JC, Mummery WK. Perceived environment and physical activity: a meta-analysis of selected environmental characteristics. Int J Behav Nutr Phys Act. 2005;2:11.

5. Bedimo-Rung AL, Mowen AJ, Cohen DA. The significance of parks to physical activity and public health: a conceptual model. Am J Prev Med. 2005;28(2 Suppl 2):159-68.

6. McCormack GR, Rock M, Toohey AM, Hignell D. Characteristics of urban parks associated with park use and physical activity: a review of qualitative research. Health Place. 2010;16(4):712-26.

7. Florindo AA, Hallal PC, Moura EC, Malta DC. Practice of physical activities and associated factors in adults, Brazil, 2006. Rev Saúde Pública. 2009;43(Supl 2):65-73.

8. Hino AA, Reis RS, Sarmiento OL, Parra DC, Brownson RC. The built environment and recreational physical activity among adults in Curitiba, Brazil. Am J Prev Med. 2011;52(6):419-22.

9. Hallal PC, Reis RS, Hino AA, Santos MS, Grande D, Krempel M, et al. Evaluation of community physical activity programs: the case of Curitiba, Brazil. Rev Bras Ativ Fís Saúde. 2009;14(2):104-14.

10. Ribeiro IC, Torres A, Parra DC, Reis R, Hoehner C, Schmid TL, et al. Using logic models as iterative tools for planning and evaluating physical activity promotion programs in Curitiba, Brazil. J Phys Act Health. 2010; 7(Suppl 2):S155-62.

11. Fermino RC, Reis RS, Cassou AC. Individual and environmental factors associated with park and plaza use in adults from Curitiba, Brazil. Rev Bras Cineantropom Desempenho Hum. 2012;14(4):377-89.

12. Fermino R, Reis R, Hallal PC, Kaczynski AT. Who are the users of urban parks? A study with adults from Curitiba, Brazil. J Phys Act Health. 2015;12(1):58-67.

13. Souza CA, Fermino RC, Rodriguez-Añez CR, Reis RS. Perfil dos frequentadores e padrão de uso das academias ao ar livre em bairros de baixa renda de Curitiba-PR. Rev Bras Ativ Fís Saúde. 2014;19(1):86-97.

14. Secretaria Municipal de Esporte, Lazer e Juventude-Academia ao ar livre. Curitiba, Brasil. 2017. [accessed in $2017 \mathrm{dec}$ 10]. Available in: http://www.curitiba.pr.gov.br/conteudo/academia-ao-ar-livre-smelj/144.

15. Costa $B G$, Freitas $C R$, Silva KS. Atividade física e uso de equipamentos entre usuários de duas academias ao ar livre. Rev Bras Ativ Fís Saúde. 2016;21(1):29-38.

16. lepsen AM, Silva M. Perfil dos frequentadores das academias do ar livre da cidade de Pelotas-RS Rev Bras Ativ Fís Saúde. 2015;20(4):413-24.

17. Cohen D, Sehgal A, Williamson S, Sturm R, McKenzie TL, Lara R, et al. Park use and physical Activity in a sample of public parks in the city of Los Angeles. Rand Health. 2006.

18. Cohen DA, McKenzie TL, Sehgal A, Williamson S, Golinelli D, Lurie N. Contribution of public parks to physical activity. Am J Public Health. 2007;97(3):509-14.

19. Rech CR, Reis RS, Hino AA, Hallal PC. Personal, social and environmental correlates of physical activity in adults from Curitiba, Brazil. Prev Med. 2014;58:53-7.

20. Salvo D, Reis RS, Hino AA, Hallal PC, Pratt M. Intensity-specific leisure-time physical activity and the built environment among brazilian adults: a best-fit model. J Phys Act Health. 2015;12(3):307-18.

21. Reis MS, Reis RS, Hallal PC. Validity and reliability of a physical activity social support assessment scale. Rev Saúde Pública. 2011;45(2):294-301.

22. Malavasi LM, Duarte MF, Both J, Reis RS. Neighborhood walkability scale (NEWS - BRAZIL): back translation and reliability. Rev Bras Cineantropom Desempenho Hum. 2007;9(4):339-50.

23. Esteves JV, Andreato LV, Moraes SM, Prati AR. Estilo de vida de praticantes de atividades físicas em academias da terceira idade de Maringá-PR. Conexões. 2010;8(1):119-29

24. Salin MS, Virtuoso JF, Nepomuceno AS, Weiers GG, Mazo GZ. Golden age gym: reasons for entry, permanence and satisfaction among participating older adults. Rev Bras Cineantropom Desempenho Hum. 2014;16(2):152-60.

25. Giles-Corti B, Broomhall MH, Knuiman M, Collins C, Douglas K, Ng K, et al. Increasing walking: how important is distance to, attractiveness, and size of public open space? Am J Prev Med. 2005;28(2 Supp 2):169-76.

26. Kaczynski AT, Potwarka LR, Saelens BE. Association of park size, distance, and features with physical activity in neighborhood parks. Am J Public Health. 2008;98(8):1451-6.

27. Reichert FF, Barros AJ, Domingues MR, Hallal PC. The role of perceived personal barriers to engagement in leisure-time physical activity. Am J Public Health. 2007;97(3):515-9.

28. Fernandes AP, Andrade AC, Ramos CG, Friche AA, Dias MA, Xavier CC, et al. Leisure-time physical activity in the vicinity of Academias da Cidade Program in Belo Horizonte, Minas Gerais State, Brazil: the impact of a health promotion program on the community. Cad Saúde Pública. 2015;31 (Suppl 1):S195-207. 